\title{
Akurasi Diagnostik Prokalsitonin Sebagai Petanda Serologis untuk Membedakan Infeksi Bakteri dan Infeksi Virus pada Anak
}

\author{
Dominicus Husada, I Gusti Ngurah Twi Adnyana, Retno Asih Setyoningrum, Darto Saharso, \\ Ismoedijanto \\ Departemen/SMF Ilmu Kesehatan Anak Fakultas Kedokteran Universitas Airlangga/RSU Dr. Soetomo, \\ Surabaya
}

\begin{abstract}
Latar belakang. Deteksi dini infeksi bakteri dan infeksi virus pada anak sangat penting untuk tata laksana antibiotik lebih dini. Prokalsitonin (PCT) merupakan suatu temuan baru sebagai petanda serologis yang bisa dipercaya. Belum banyak informasi tentang akurasi diagnostik PCT untuk spektrum penyakit infeksi di negara berkembang.

Tujuan. Melakukan akurasi diagnostik PCT sebagai petanda serologis untuk membedakan infeksi bakteri dan infeksi virus pada anak.

Metode. Penelitian prospektif dengan desain potong lintang dilakukan di Departemen Ilmu Kesehatan Anak RSU Dr. Soetomo Surabaya, dari September 2009 sampai November 2010. Pasien dibagi dalam kelompok infeksi bakteri dan infeksi virus (sebagai kontrol). Data demografi, pemeriksaan darah tepi, CRP and PCT dievaluasi. Analisis statistik menggunakan uji student $\mathrm{t}$ dan uji Mann Whitney U dengan interval kepercayaan $95 \%$ dan bermakna jika nilai $\mathrm{p}<0,05$. Dilakukan perhitungan sensitivitas, spesifisitas, nilai duga positif (NDP), nilai duga negatif (NDN) dan rasio kemungkinan (RK)

Hasil. Di antara 130 pasien yang terkumpul didapatkan 54 sampel untuk tiap kelompok. Ditemukan perbedaan kadar PCT yang bermakna antara kelompok infeksi bakteri dibandingkan infeksi virus (rerata 18,34 dan 0,22 ng/ml, p<0,0001). Dengan menggunakan kadar 0,5 ng/ml sebagai kadar ambang (sesuai penelitian sebelumnya) didapatkan sensitivitas $88,9 \%$, spesifisitas $94,4 \%$, NDP $94,1 \%$, NDN $89,4 \%$ dengan RK positif 15,87 dan RK negatif 0,09.

Kesimpulan. Prokalsitonin merupakan petanda serologis dengan akurasi diagnostik yang tinggi untuk membedakan infeksi bakteri dan infeksi virus pada anak. Sari Pediatri 2012;13(5):316-23.
\end{abstract}

Kata kunci: anak, prokalsitonin, infeksi bakteri, infeksi virus, akurasi diagnostik

Alamat korespondensi:

Dr. Dominicus Husada, Sp.A, DTM\&H., MCTM (TP), Kertajaya Indah VII / 9 ( G-121 ), Surabaya 60116. Telp. (031) 5947807, 0818337734, Fax. (031) 5501748. E-mail: dominicushusada@yahoo.com

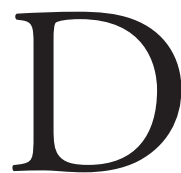
ata WHO tahun 2000 menunjuk peningkatan prevalensi infeksi bakteri mencapai 9\% di seluruh dunia dalam satu dasawarsa terakhir. ${ }^{1}$ Permasalahan utama 
dalam tata laksana infeksi bakteri adalah identifikasi etiologi secara dini dan pemberian antibiotik yang rasional. Pemberian antibiotik yang tertunda pada infeksi bakteri akan menyebabkan perjalanan penyakit semakin parah dengan komplikasi lebih lanjut. Sebaliknya pemberian antibiotik berlebihan untuk penyakit virus atau penyakit non infeksi menimbulkan dampak sama besar apabila pemberian antibiotik ditunda. Diagnosis infeksi bakteri masih merupakan tantangan tersendiri karena presentasi klinis mirip dengan penyakit infeksi dengan penyebab yang berbeda., ${ }^{2,3}$

Nigrovic ${ }^{4}$ dalam penelitiannya di Amerika melaporkan peningkatan gejala sisa defisit neurologis dan gangguan pendengaran sampai $25 \%$ pada anak dengan meningitis bakterial akut yang disebabkan pemberian antibiotik yang tertunda. Di lain pihak beberapa penelitian di Kanada dan Amerika melaporkan bahwa penulisan antibiotik secara berlebihan pada anak mencapai 50\% dari seluruh pembuatan resep. ${ }^{2}$ Penelitian WHO tahun 2000 melaporkan bahwa dari setiap 100 anak dengan infeksi pernafasan, hanya 20 yang terindikasi memerlukan terapi antibiotik. ${ }^{1} \mathrm{Di}$ Indonesia, Kartasasmita $\mathrm{dkk}^{5}$ dalam sebuah penelitian epidemiologi tahun 2001 melaporkan tingkat resistensi antibiotik pada anak dengan pneumonia mencapai $48 \%$ dan hanya $19 \%$ yang sensitif. Sementara kelompok peneliti Antimicrobial Resistance in Indonesia (AMRIN) dalam penelitian di RS Dr. Soetomo Surabaya mendapatkan tingkat resistensi terhadap antibiotik untuk dua bakteri komensal yaitu Escherichia coli dan Staphylococcus aureus pada penyakit infeksi lini pertama mencapai $90 \%$ dan pada penyakit infeksi lini kedua mencapai 50\%.6,7

Prokalsitonin (PCT) suatu prekursor hormon kalsitonin, merupakan petanda serologis infeksi bakteri yang makin banyak diteliti. Penelitian tersebut banyak dilakukan di negara maju yang mempunyai spektrum penyakit infeksi yang berbeda dengan negara berkembang seperti Indonesia. Belum banyak diketahui peran PCT untuk identifikasi etiologi pada spektrum penyakit infeksi yang banyak didapatkan di negara berkembang. Angka kematian akibat penyakit infeksi di negara berkembang cenderung meningkat tajam karena pemberian antibiotik yang tertunda namun di lain pihak angka kejadian resistensi antibiotik juga semakin banyak akibat penggunaan antibiotik yang tidak rasional. Penelitian kami dimaksudkan untuk mengetahui akurasi diagnostik PCT sebagai petanda diagnostik untuk membedakan infeksi bakteri atau virus di Surabaya.

\section{Metode}

Di Instalasi Rawat Darurat RSU Dr.Soetomo Surabaya, dilakukan pengambilan sampel penelitian dengan kriteria inklusi anak usia 3 bulan - 12 tahun dengan suhu tubuh $38,5^{\circ} \mathrm{C}$ pada pemeriksaan aksila dan ada persetujuan dari orang tua. Kriteria eksklusi meliputi anak dengan riwayat pemberian antibiotik dalam 24 jam sebelumnya, anak dengan penyakit autoimun atau keganasan, sedang atau dalam terapi steroid lebih dari 2 minggu, pasca bedah dan pasca vaskinasi dalam periode 7 hari sebelumnya. Penelitian telah mendapat sertifikat kelayakan etik dari Panitia Etik Penelitian RSU dr. Soetomo Surabaya.

Melalui perhitungan data tahun sebelumnya mengenai jumlah anak yang masuk perawatan dengan keluhan utama demam $>38,5^{\circ} \mathrm{C}$ didapatkan besar sampel minimal yang diperlukan 101 anak. Pada seluruh pasien dilakukan anamnesis, pencatatan suhu tubuh dan pemeriksaan fisis sesuai prosedur. Selanjutnya dilakukan pemeriksaan darah lengkap dan pengambilan sampel serum untuk disimpan guna pemerikaan PCT dan CRP (c-reactive protein). Selanjutnya pasien diikuti di ruangan untuk tindak lanjut penegakan diagnosis definitif dan dilakukan pemeriksaan CRP dan PCT pada spesimen yang sudah disimpan sebelumnya.

Definisi dan kriteria infeksi bakteri adalah, 1) Sepsis disertai hasil biakan darah terdapat pertumbuhan kuman ${ }^{8}$; 2) Pneumonia bakteri, sesuai Bacterial Pneumonia Score dari Moreno, 2006, kemungkinan etiologi bakteri jika skor $\geq 4,9$ 3) Meningitis bakterialis, dengan hasil pleositosis cairan serebro spinal (CSS) dan berdasarkan Bacterial Meningitis Score dari Nigrovic, 2002, ${ }^{4}$ kemungkinan etiologi bakteri jika skor $>2 ; 4)$. Demam tifoid, berdasarkan manifestasi klinik dan pemeriksaan IgM Salmonella dan dengan indeks diagnostik visual $>4{ }^{10}$; dan 5) Difteria dengan tanda patognomonik pseudomembran dan hasil usap tenggorok yang positif. ${ }^{11}$ Kelompok infeksi virus sebagai kelompok kontrol dalam penelitian ini adalah 1) Infeksi dengue, dengan kriteria diagnosis sesuai panduan WHO tahun 2009; dan 2) Morbili, dengan manifestasi spesifik demam, batuk, pilek, 
konjungtivitis, dan ruam kulit sesuai kriteria. Subjek dikelompokkan dalam kelompok infeksi bakteri dan infeksi virus. ${ }^{2-13}$

Pemeriksaan PCT mutakhir menggunakan metode enzyme-linked fluorescent immunoassay (ELFA) yang merupakan suatu pemeriksaan kuantitatif cepat yang dirancang khusus untuk kegawatdaruratan. Pemeriksaan ELFA mempunyai sensitivitas fungsional sampai $0,09 \mathrm{ng} / \mathrm{ml}$. Perangkat yang digunakan adalah mini VIDAS ${ }^{\mathrm{TM}} \mathrm{B} \cdot \mathrm{R} \cdot \mathrm{A} \cdot \mathrm{H} \cdot \mathrm{M} \cdot \mathrm{S}$ PCT. ${ }^{14}$

Analisis statistik menggunakan interval kepercayaan $95 \%$ dan $\mathrm{p}<0.05$. Uji normalitas dilakukan dengan uji Kolmogorov-Smirnov. Untuk data kontinu terdistribusi normal digunakan sudent $t$ test dan untuk data yang lain dengan MannWhitney $U$ test. Selanjutnya dilakukan perhitungan akurasi diagnostik PCT yang meliputi sensitivitas, spesifisitas, nilai duga positif (NDP), nilai duga negatif (NDN), dan rasio kemungkinan (RK). Rasio Kemungkinan untuk uji positif $(\mathrm{RK}+)$ dihitung dengan formula sensitivitas /(1 - spesifisitas). Selain itu dicari pula nilai ambang dengan akurasi terbaik.

\section{Hasil}

Selama periode pengumpulan sampel didapatkan 130 spesimen serum, 22 di antaranya tidak memenuhi persyaratan untuk diperiksa (hemolisis, lipemik, dan volume serum tidak cukup). Maka akhirnya diperoleh 108 spesimen sampel yang layak dan terbagi dalam dua kelompok dengan jumlah yang seimbang.

Pada penelitian kami tidak didapatkan perbedaan yang bermakna di antara kedua kelompok uji untuk variabel umur, berat badan, dan rasio jenis kelamin laki dan perempuan (Tabel 1). Distribusi diagnosis pada kedua kelompok uji tertera pada Tabel 2. Distribusi diagnosis adalah spektrum penyakit yang banyak didapatkan di Indonesia.

Dari 13 pasien sepsis, didapatkan hasil biakan darah Klebsiella pneumoniae pada 4 anak, Staphylococcus aureus pada 1 anak, Staphylococcus coagulase negative pada 3 anak, Acinetobacter spp pada 4 anak, dan Pseudomonas aeruginosa pada 1 anak. Semua anak mendapatkan perawatan intensif dan tiga diantaranya dengan perawatan ventilasi mekanik. Salah satu anak dengan hasil biakan Klebsiella pneumoniae juga disertai hasil Klebsiella positif dengan ESBL pada biakan urin.

Tabel 1. Karakteristik subjek penelitian

\begin{tabular}{lccc}
\hline Variabel & $\begin{array}{c}\text { Kelompok } \\
\text { infeksi bakteri } \\
(\mathrm{n}=54)\end{array}$ & $\begin{array}{c}\text { Kelompok } \\
\text { infeksi virus } \\
(\mathrm{n}=54)\end{array}$ & $p$ \\
\hline Umur, bulan, rerata $(95 \% \mathrm{CI})$ & $33,17(22,71-44,46)$ & $24,56(19,33-30,18)$ & 0,850 \\
Berat badan, kg, rerata (95\% CI) & $12,73(10,61-14,95)$ & $12,23(10,65-13,81)$ & 0,622 \\
Suhu tubuh, $^{\circ} \mathrm{C}$, rerata $(95 \% \mathrm{CI})$ & $39,61(39,32-39,84)$ & $39,07(38,88-39,26)$ & $\left.0,005^{*}\right)$ \\
Jenis kelamin, laki : perempuan, \% & $66,7: 33,3$ & $57,4: 42,6$ & 0,428 \\
\hline
\end{tabular}

*) bermakna, bila $\mathrm{p}<0,05$; CI : confidence interval;

Tabel 2. Distribusi diagnosis

\begin{tabular}{lcc}
\hline Diagnosis & $\begin{array}{c}\text { Kelompok } \\
\text { infeksi bakteri } \\
(\mathrm{n}=54)\end{array}$ & $\begin{array}{c}\text { Kelompok } \\
\text { infeksi virus } \\
(\mathrm{n}=54)\end{array}$ \\
\hline Sepsis & 13 & - \\
Pnemonia bakteri & 16 & - \\
Meningitis bakterialis & 10 & - \\
Demam tifoid & 10 & - \\
Difteria & 5 & 23 \\
Morbili & - & 31 \\
Infeksi virus dengue & - & \\
\hline
\end{tabular}

Total Sampel 108 subjek 
Sementara anak dengan hasil biakan Staphylococcus aureus menunjukkan lesi kulit yang sesuai dengan gambaran khas infeksi Staphylococcus.

Sebagian besar dari sepuluh anak dengan meningitis bakterialis datang ke rumah sakit dengan keluhan demam tinggi, riwayat penurunan kesadaran dengan atau tanpa disertai kejang. Hampir seluruh pasien menunjukkan manifestasi rangsangan meningeal. Di antara 10 anak dengan meningitis bakterialis didapatkan 7 anak dengan hasil pengecatan gram pada CSS yang positif dan 3 negatif. Semua pasien menunjukan gambaran pleositosis pada analisis CSS dengan absolute neutrofil count (ANC) pada sel CSS berkisar antara 1500-3000 sel. Lima anak menunjukkan hasil skor diagnostik meningitis bakteri 5, satu anak dengan skor maksimal dan 4 anak dengan skor berkisar antara 3 sampai 4 .

Pada kelompok pneumonia bakteri, semua masuk dengan manifestasi klinis khas adanya nafas cepat dan tarikan dinding dada. Pada penilaian dengan skor diagnosis pnemonia bakteri dari Moreno didapatkan poin antara 4 sampai 10 . Korelasi antara hasil skor dengan kadar PCT tampakberbanding lurus (data tidak ditampilkan). Diagnosis demam tifoid ditegakkan berdasarkan manifestasi klinis demam tinggi dengan kisaran $38,5^{\circ} \mathrm{C}-39,5^{\circ} \mathrm{C}$ disertai dengan gejala pencernaan. Pemeriksaan serologis IgM anti
Salmonella dinilai positif jika skor semikuantitatif visual lebih dari 5 (metode IMBI). Didapatkan 10 anak dengan diagnosis demam tifoid berdasarkan manifestasi klinis yang khas dan hasil pemeriksaan IgM anti salmonella dengan skor semikuantitatif visual antara 6-10. Satu anak mengalami perforasi dan menjalani laparatomi eksplorasi.

Pada kasus difteria didapatkan 5 subjek yang memenuhi syarat dengan manifestasi klinik khas adanya pseudomembran dan pembesaran kelenjar limfe disertai dengan hasil pemeriksaan usap tenggorok yang positif terhadap Corynebacterium diphteriae Pasien yang secara klinis dirawat sebagai difteria (dengan isolasi khusus) tidak dimasukan sebagai subjek penelitian apabila hasil pemeriksaan usap tenggorok negatif.

Pada kelompok infeksi virus didapatkan 54 subjek, 31 anak menderita infeksi virus dengue, dan 23 anak dengan morbili. Diagnosis infeksi virus dengue ditegakkan berdasarkan manifestasi klinis dan pemeriksaan darah tepi sesuai dengan kriteria WHO (2009). Pada kelompok infeksi virus dengue didapatkan 11 anak dengan dengue berat dan 20 anak dengan presumtif dengue baik tanpa maupun dengan tanda bahaya (warning sign). Sepuluh anak dengan demam berdarah menjalani perawatan intensif karena mengalami syok. Semua pasien dengan infeksi virus

Tabel 3. Perbandingan gambaran darah tepi pada kedua kelompok uji

\begin{tabular}{lcc}
\hline Variabel & $\begin{array}{c}\text { Kelompok } \\
\text { infeksi bakteri } \\
(\mathrm{n}=54)\end{array}$ & $\begin{array}{c}\text { Kelompok } \\
\text { infeksi virus } \\
(\mathrm{n}=54)\end{array}$ \\
\hline Hemoglobin $(\mathrm{g} / \mathrm{dl})$ & $11,25(10,83-11,67)$ & $12,37(11,77-12,97)$ \\
Hitung lekosit $\left(\mathrm{x} 10^{3} / \mathrm{mm}^{3}\right)$ & $16,69(14,80-18,60)$ & $8,47(7,09-10,10)$ \\
Trombosit $\left(\mathrm{x} 10^{3} / \mathrm{mm}^{3}\right)$ & $243,89(215,50-279,65)$ & $226,85(182,90-271,23)$ \\
IT Ratio $(\%)$ & $34,30(30,66-38,35)$ & $27,94(23,60-31,72)$ \\
\hline
\end{tabular}

Nilai dinyatakan dalam rerata $(95 \% \mathrm{CI})$

*) bermakna jika $\mathrm{p}<0,05$; IT Ratio = immature total ratio ; $\mathrm{CI}=$ confidence interval

Tabel 4. Perbandingan kadar CRP dan PCT pada kedua kelompok uji

\begin{tabular}{lccc}
\hline Variabel & $\begin{array}{c}\text { Kelompok } \\
\text { infeksi bakteri } \\
(\mathrm{n}=54)\end{array}$ & $\begin{array}{c}\text { Kelompok } \\
\text { infeksi virus } \\
(\mathrm{n}=54)\end{array}$ & $p$ \\
\hline CRP $(\mathrm{mg} / \mathrm{l})$ & $31,80(15,91-47,69)$ & $13,57(6,47-20,67)$ & 0,299 \\
PCT $(\mathrm{ng} / \mathrm{ml})$ & $18,34(7,68-29,67)$ & $0,22(0,16-0,27)$ & $<0,0001^{*}$ \\
\hline
\end{tabular}

Nilai dinyatakan dalam rerata $(95 \% \mathrm{CI})$

*) bermakna jika $\mathrm{p}<0,05, \mathrm{PCT}=$ prokalsitonin, $\mathrm{CRP}=\mathrm{C}$-reactive protein 
dengue diikutsertakan dalam penelitian berdasarkan gambaran darah tepi leukopenia dengan hitung leukosit berkisar antara $2500-3800 / \mathrm{mm}^{3}$ dan terdapat trombositopenia.

Pemeriksaan darah tepi menunjukkan perbedaan diantara kedua kelompok uji. Kadar hemoglobin pada kelompok infeksi bakteri relatif lebih rendah dibandingkan dengan kelompok infeksi virus. Untuk hitung leukosit dan IT ratio didapatkan hasil yang lebih tinggi pada kelompok infeksi bakteri. Hitung trombosit pada kelompok infeksi bakteri (rerata 243898,15 per $\mathrm{mm}^{3}$ ) relatif lebih tinggi dibandingkan dengan infeksi virus (rerata 224850,00 per $\mathrm{mm}^{3}$ ).

Kadar PCT dan CRP tertera pada Tabel 4. Untuk PCT pada kelompok infeksi bakteri didapatkan

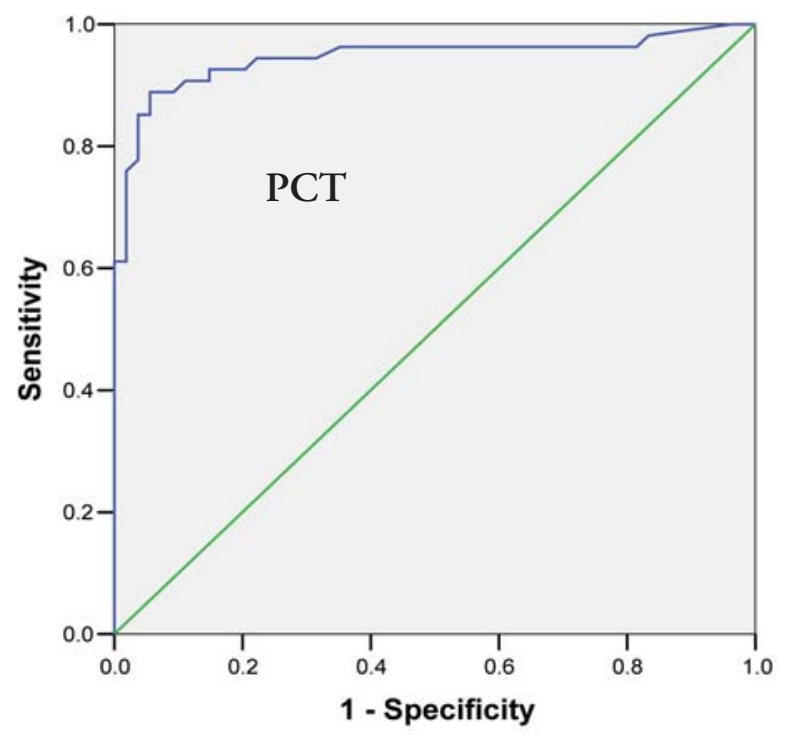

Diagonal segments are produced by ties.

Gambar 1. Kurva ROC akurasi diagnostik kadar PCT Luas area kurva ROC 0,94 (0,89-0,99) kadar yang lebih tinggi sementara untuk CRP tidak ditemukan perbedaan yang bermakna antara kedua kelompok.

Dengan menggunakan nilai batas ambang kadar PCT $0,5 \mathrm{ng} / \mathrm{ml}$ (sesuai dengan kadar ambang diagnostik secara internasional), didapatkan akurasi diagnostik prokalsitonin, sensitivitas $88,9 \%$, spesifisitas 94,4\%, NDP 94,1\%, NDN 89,4\%, RK positif 15,87 dan RK negatif 0,09. Dari perhitungan statistik didapatkan nilai RK 88,54 dengan $\mathrm{p}<0,0001$, nilai asosiasi kappa 0,833 dengan $\mathrm{p}<0,0001$ dan uji $\mathrm{McNemar}$ dengan $\mathrm{p}=0,508$. Luas area di bawah kurva ROC adalah 0,94 dengan $\mathrm{p}<0,001$ (Gambar 1).

Pada penelitian kami didapatkan pula dua nilai baru yang memenuhi syarat sebagai ambang diagnostik yaitu $0,430 \mathrm{ng} / \mathrm{ml}$ dan $0,505 \mathrm{ng} / \mathrm{ml}$. Akurasi diagnostik untuk kadar ambang $0,430 \mathrm{ng} / \mathrm{ml}$ dan $0,505 \mathrm{ng} / \mathrm{ml}$ tertera pada Tabel 5.

Berdasarkan ketentuan dan persyaratan bahwa kadar ambang terbaik suatu uji diagnostik adalah kadar ambang dengan nilai RK yang paling tinggi maka pada penelitian kami kadar ambang baru yang paling baik adalah $0,505 \mathrm{ng} / \mathrm{ml}$ atau relatif sama dengan kadar ambang diagnostik yang disepakati secara internasional.

\section{Pembahasan}

Prokalsitonin merupakan suatu petanda serologis dalam bentuk prohormon yang makin banyak diteliti perannya sebagai determinan etiologi pada penyakit infeksi. Assicott ${ }^{15}$ pertama kali menemukan kadar PCT sangat meningkat pada pasien dengan sepsis. Setelah itu Dandona ${ }^{16}$ dan Whang ${ }^{17}$ melaporkan kadar PCT meningkat dramatis dengan rangsangan oleh endotoksin. Hatheril ${ }^{18}$ mendapatkan keunggulan PCT untuk menentukan etiologi bakteri dan non-bakteri pada penyakit infeksi. Lacour ${ }^{19}$ meneliti keunggulan

Tabel 5. Kadar ambang terbaik prokalsitonin

\begin{tabular}{lccccccc}
\hline $\begin{array}{l}\text { Kadar ambang } \\
\text { PCT }(\mathrm{ng} / \mathrm{ml})\end{array}$ & $\begin{array}{c}\text { Sensitivitas } \\
(\%)\end{array}$ & $\begin{array}{c}\text { Spesifisitas } \\
(\%)\end{array}$ & $\begin{array}{c}\text { NDP } \\
(\%)\end{array}$ & $\begin{array}{c}\text { NDN } \\
(\%)\end{array}$ & RK+ & RK - & Nilai RK \\
\hline 0,430 & 90,7 & 88,9 & 89,0 & 90,0 & 9,96 & 0,10 & 78,69 \\
0,505 & 88,9 & 94,4 & 94,1 & 89,4 & 15,87 & 0,09 & 88,54 \\
\hline
\end{tabular}

Bermakna jika $\mathrm{p}<0,05$

NDP: Nilai Duga Positif; NDN : Nilai Duga Negatif; RK+ : Rasio kemungkinan positif; RK - : Rasio Kemungkinan Negatif 
PCT dibandingkan dengan analisis darah tepi dan CRP sebagai petanda spesifik dari infeksi bakteri. Selanjutnya Feezor ${ }^{20}$ menemukan bahwa peningkatan PCT bukan hanya dirangsang oleh endotoksin dari bakteri gram negatif, tetapi juga oleh materi dinding sel bakteri gram positif. Crain ${ }^{21}$ merekomendasikan penggunaan kadar PCT sebagai dasar pemberian antibiotik pada pasien pneumonia.

Studi kami merupakan satu di antara penelitian yang dilakukan di negara berkembang yang menyangkut peran PCT sebagai petanda penyakit infeksi dan dilakukan pada penyakit infeksi dengan spektrum luas baik bakteri maupun virus dengan prevalensi dan insiden yang masih tinggi. Fokus dari penelitian kami adalah penggunaan PCT pada kelompok infeksi bakteri dibandingkan dengan kelompok infeksi virus.

Berbagai penelitian PCT di negara maju menggunakan subyek satu jenis penyakit infeksi bakteri sehingga sering menimbulkan hasil yang berbeda. Korppi $^{22}$ menyatakan PCT tidak dapat digunakan untuk identifikasi etiologi bakteri pada pneumonia. Sebaliknya Crain ${ }^{21}$ merekomendasikan panduan pemberian antibiotik berdasarkan kadar PCT serum dengan rentang $0,5 \mathrm{ng} / \mathrm{ml}-10 \mathrm{ng} / \mathrm{ml}$. Fiorreto ${ }^{23}$ menyatakan kadar $10 \mathrm{ng} / \mathrm{ml}$ merupakan ambang diagnosis sepsis dan syok septik pada anak di ruang intensif. Sementara itu belum banyak penelitian dengan hasil yang tegas menyatakan peran PCT sebagai determinan infeksi bakteri dan virus secara menyeluruh dengan cakupan penyakit yang luas sehingga bisa digunakan sebagai penentu tindak lanjut pada saat awal perawatan pada anak yang diprediksi memerlukan tata laksana antimikroba.

Temuan kami secara konsisten menunjukkan perbedaan kadar PCT yang bermakna antara kelompok infeksi bakteri dengan virus. Pada infeksi virus didapatkan kadar PCT yang selalu rendah dengan kisaran kadar dibawah kadar ambang diagnostik secara internasional yaitu $0,5 \mathrm{ng} / \mathrm{ml}$. Hal tersebut sejalan dengan banyak penelitian sebelumnya yang walaupun menunjukkan kadar ambang yang bervariasi, tetap menunjukkan hasil yang cenderung lebih rendah pada infeksi virus. Subkelompok pneumonia dengan skor diagnostik Moreno ${ }^{9}$ kurang dari 4 menunjukkan kadar PCT yang konsisten di bawah nilai ambang diagnostik. Temuan kami sesuai dengan sebagian besar penelitian sebelumnya tentang peran PCT pada infeksi virus. ${ }^{24}$
Pada lima kasus difteria didapatkan rentang kadar PCT yang relatif sama dengan kelompok infeksi virus secara keseluruhan. Belum pernah ada penelitian tentang PCT pada difteria sebagai salah satu diagnosis dalam subkelompok penelitian. Kadar PCT yang relatif rendah pada difteria kemungkian besar terkait dengan mekanisme patologis dari difteria yang berperan dalam menimbulkan lesi patologis adalah eksotoksin dalam peredaran darah yang disekresi oleh kuman Corynebacterium diphteriae dan bukan karena produk material sel bakteri sendiri. Sementara itu peran mediator proinflamasi pada difteria terjadi pada fase lanjut dari penyakit. Temuan kami semakin memperkuat hasil penelitian sebelumnya tentang hubungan infeksi bakteri dengan kadar PCT bahwa peningkatan kadar PCT pada sirkulasi sistemik dirangsang oleh paparan dari material dinding sel bakteri baik bakteri gram positif (proteoglikan) maupun bakteri gram negatif (endotoksin) dan juga rangsangan dari sitokin proinflamasi (terutama dalam hal ini TNF- $\alpha$ maupun IL-1 $\beta$ ) dan bukan karena produk toksin dari bakteri bersangkutan. Dengan kata lain, hasil penelitian kami juga sesuai dengan hasil penelitian in vitro yang sudah dilakukan sebelumnya bahwa rangsangan eksotoksin yang berada di dalam sirkulasi tidak mempengaruhi kadar PCT. ${ }^{25}$

Kami mendapatkan kadar PCT pada pneumonia bakteri cenderung lebih rendah dibandingkan kasus sepsis, meningitis bakteri, dan demam tifoid, walaupun tetap lebih dari $0,5 \mathrm{ng} / \mathrm{ml}$ yang merupakan kadar ambang diagnostik infeksi bakteri secara internasional. Temuan kami juga sesuai dengan beberapa penelitian sebelumnya. Moulin ${ }^{24}$ mendapatkan kadar ambang diagnostik untuk menentukan etiologi bakteri pada pneumonia berkisar antara $1 \mathrm{ng} / \mathrm{ml}$ sampai $2 \mathrm{ng} / \mathrm{ml}$. Crain $^{21}$ merekomendasikan beberapa rentang kadar PCT sebagai panduan tata laksana antibiotik pada pneumonia yang berkisar antara $0,5 \mathrm{ng} / \mathrm{ml}$ sampai $10 \mathrm{ng} / \mathrm{ml}$, dan keputusan tata laksana antibiotik berdasarkan rentang kadar tersebut.

Beberapa ahli menyatakan bahwa patogenesis pneumonia didahului dengan paparan bakteri dalam sirkulasi sistemik yang kemudian ikut aliran darah sampai ke sel langerhans paru dan menimbulkan reaksi peradangan paru. Kelompok tersebut menganjurkan pemeriksaan biakan darah untuk penegakan diagnosis. Namun kelompok lain menyatakan pneumonia merupakan suatu infeksi yang didahului infeksi saluran nafas akut 
yang kemudian menyebabkan inflamasi alveoli dan selanjutnya terjadi konsolidasi jaringan paru. Maka kelompok ini merekomendasikan penegakkan diagnosis pneumonia dengan pemeriksaan biakan cairan paru dan sputum. ${ }^{26}$ Moreno9 merekomendasikan untuk menegakkan diagnosis pneumonia bakteri pada anak berdasarkan kombinasi dari manifestasi klinis, gambaran darah tepi, dan foto polos dada.

Demam tifoid pada anak mempunyai kadar PCT lebih tinggi secara bermakna dibandingkan dengan infeksi virus. Temuan kami tersebut menjawab penelitian Dandona $\mathrm{dkk}^{16}$ yang menyatakan bahwa sekresi PCT dipengaruhi oleh endotoksin yang sebelumnya dilakukan pada binatang coba. Kami juga membuktikan peran PCT yang meningkat pada penyakit dengan dasar patogenesis adanya endotoksinemia seperti demam tifoid. Interpretasi nilai diagnostik PCT selama ini masih merupakan suatu kendala aplikasi praktis. Hal tersebut karena banyak variasi pilihan nilai "kadar ambang abnormal" dari PCT. Beberapa faktor yang menyebabkan bervariasi kadar ambang antara lain karena penelitian sebelumnya menggunakan kategori beragam dan berbeda satu sama lain untuk klasifikasi subjek seperti "sepsis", "infected", ataupun "distress". Sementara ini kadar 0,5 $\mathrm{ng} / \mathrm{ml}$ disepakati secara umum sebagai kadar ambang diagnostik PCT walaupun beberapa institusi masih menggunakan nilai ambang yang berbeda. ${ }^{3,18}$

Hasil pada penelitian kami menunjukkan bahwa dengan menggunakan nilai batas ambang kadar PCT sebesar $0,5 \mathrm{ng} / \mathrm{ml}$ didapatkan akurasi diagnostik PCT dengan sensitivitas $88,9 \%$, spesifisitas $94,4 \%$, nilai ramal positif $94,1 \%$ dan nilai ramal negatif $89,4 \%$. Pada penelitian kami didapatkan pula ambang kadar diagnostik yaitu $0,43 \mathrm{ng} / \mathrm{ml}$ dan $0,505 \mathrm{ng} / \mathrm{ml}$ sebagai nilai dengan akurasi terbaik. Luas area di bawah kurva $R O C$ adalah 0,94 (95\% CI 0,89-0,99). Temuan kami relatif sama dengan hasil penelitian dari Hatheril ${ }^{18}$ tahun 1999 tentang peran PCT pada anak dengan infeksi bakteri serius. Pada penelitian Hatheril tersebut didapatkan luas area pada kurva $R O C$ untuk PCT sebagai petanda syok septik pada anak adalah 0,96 (CI 95\%, 0,93-0,99).

Sebagai kesimpulan, pemeriksaan kadar PCT plasma mempunyai akurasi yang tinggi dalam membedakan infeksi bakteri dan virus pada anak. Kadar ambang dengan akurasi terbaik dari penelitian ini adalah $0,505 \mathrm{ng} / \mathrm{ml}$ dan hampir sama dengan kadar ambang secara internasional.

\section{Daftar pustaka}

1. World Health Organisation. WHO report on infectious disease: overcoming antimicrobial resistance. Geneva: WHO; 2000.

2. Bronzowaer SL, Buchhol U, Kool JL. International surveilance of antimirobial resistance in Europe : now we also need to monitor antibiotic use. Euro Surveillance 2006;6:1-16.

3. Simon D, Gauvin F, Amre DK, Louis P, Lacroix J. Serum procalcitonin and $\mathrm{C}$-reactive protein level as markers of bacterial infection : a systematic review and metaanalysis. Clin Infect Dis 2004; 39:206-17.

4. Nigrovic LE, Kupperman N, Malley R. Development and validation of a multivariable predictive model to distinguish bacterial from aseptic meningitis in children in the post-Haemophilus influenzae era. Pediatrics 2002; 110:712-9.

5. Kartasasmita CB, Melinda H, Sudigdoadi S, Agustian D, Setiowati I, Ahmad TH. Nasopharyngeal bacterial carriage and antimicrobial resistance in underfive children with community acquired pneumonia. Paediatr Indones 2001;41:292-5.

6. Ismoedijanto. Antibiotika dan resistensi antimikrobial pada anak. Dalam: Simposium Penyakit Infeksi dan Pediatri Tropik dan Gawat Darurat Anak - Tata Laksana Terkini Penyakit Tropis dan Gawat Darurat pada Anak. Surabaya : IDAI Cabang Jatim; 2005. h.1-16.

7. Lestari ES, Severin JA, Fillus PMG, Kuntaman $\mathrm{K}$, Duering DO. Antimicrobial resistance among commensal isolates of Escherichia coli and Staphylococcus aureus in the Indonesian population inside and outside hospital. Eur J Clin Microbiol \& Infect Dis 2008;27:45-51.

8. Goldstein B, Giroir B, Randolph A, International pediatric sepsis consensus conference: definitions for sepsis and organ dysfunction in pediatrics. Pediatr Crit Care Med 2005; 6: 2-5.

9. Moreno L, Krishnan, Duran P, Ferreo F. Development and validation of a clinical prediction rule to distinguish bacterial from viral pneumonia in children. Pediatr Pulmonol 2006;41:331-7.

10. Kawano RL, Leano SA, Agdamag DM. Comparison of serological test kits for diagnosis of typhoid fever in The Philippines. J Clin Microbiol 2007;145: 246-7.

11. Efstratiou A, Engler KH, Mazurova IK, dkk. Current approaches to the laboratory diagnosis of diphtheria. J Infect Dis 2000; 181:138-45. 
Dominicus Husada dkk: Akurasi diagnostik PCT sebagai petanda serologis untuk membedakan infeksi bakteri dan infeksi virus

12. World Health Organization. Dengue guidelines for diagnosis, treatment, prevention and control. Geneva: WHO; 2009.

13. Katz SL. Measles. Dalam: Katz SL, Gershon AA, Hotez PJ, penyunting. Krugman's Infectious Diseases of Children, edisi kedelapan. St. Louis: Mosby Year Book; 1998. h. 247-64.

14. Kim KE, Han JY. Evaluation of the clinical performance of an automated procalcitonin assay for the quantitative detection of bloodstream infection. Korean J Lab Med 2010;30:153-9.

15. Assicot M, Gendrel D, Carsin H, Raymond J, Guilbaud J, Bohuon C. High serum procalcitonin consentration in patients with sepsis and infection. Lancet 1993;41:515-8.

16. Dandonna P, Nix D, Wilson WF, Aljada A, Assicott $\mathrm{M}$, Bohuon C. Procalcitonin increases after endotoxin injection in normal subjects. J Clin Endocrinol Metab 1994;79:1605 - 8 .

17. Whang KT, Steinwald PM, White JC, Nylen ES, Snider RH, Simon GL. Serum calcitonin precursors in sepsis and systemic inflammation. J Clin Endocrinol Metab 1998;83 : 3296-301.

18. Hatheril M, Tibby SM, Sykes K, Turner C, Murdoch IA. Diagnostic marker of infection : comparison of procalcitonin with C-reactive protein and leucocyte count. Arch Dis Child 1999;81: 417-21.

19. Lacour AG, Zamora SA, Gervaix A. Bedside procalcitonin and C-reactive protein tests in children with fever without localizing signs of infection seen in a referral centre. Pediatrics 2003;112:1054-60.

20. Feezor RJ, Caroline O, Baker V. Molecular characterization of the acute inflammatory response to infection with gram-negative versus gram positive bacteria. Infect and Immun 2003;71:5803-13.

21. Crain MC, Müller B. Biomarkers in respiratory tract infections: diagnostic guides to antibiotic prescription, prognostic markers and mediators. Eur Respir J 2007; 30:556-73.

22. Korppi M, Remes S, Heiskanen-Kosma T. Serum procalcitonin concentrations in bacterial pneumonia in children: a negative result in primary healthcare settings. Pediatr Pulmonol 2003; 35:56-61.

23. Fioretto JR, Borin FC, Bonatto RC, dkk. Procalcitonin in children with sepsis and septic shock. J Pediatr 2005:83:323-8.

24. Moulin F, Raymond J, Lorrot M, Marc E, Coste J, Iniguez J. Procalcitonin in children admitted to hospital with community acquired pneumonia. Arch Dis Child 2001;84:332-6.

25. Linscheid P, Seboek D, Nylen ES, dkk. In vitro and in vivo calcitonin I gene expression in parenchymal cells: a novel product of human adipose tissue. Endocrinology 2003; 144 : 5578-84

26. Cherian T. Describing the epidemiology and aetiology of bacterial pneumonia in children: an unresolved problem. J Health Popul Nutr 2005;23:1-5. 